\title{
Antimicrobial resistance in staphylococci from animals with particular reference to bovine Staphylococcus aureus, porcine Staphylococcus hyicus, and canine Staphylococcus intermedius
}

\author{
Christiane WERCKENTHIN ${ }^{\mathrm{a}}$, Marisa CARDOSO ${ }^{\mathrm{b}, \mathrm{d}}$, \\ Jean-Louis MARTEL ${ }^{\mathrm{c}}$, Stefan SCHWARZ ${ }^{\mathrm{d} *}$ \\ ${ }^{a}$ Institut für Medizinische Mikrobiologie, Infektions- und Seuchenmedizin, \\ Tierärztliche Fakultät, Ludwig-Maximilians-Universität München, \\ 80539 München, Germany \\ ${ }^{\text {b }}$ Departamento de Medicina Veterinária Preventiva, Faculdade de Veterinária da Universidade \\ Federal do Rio Grande do Sul, 91540-000 Porto Alegre, Brazil \\ ${ }^{c}$ Agence Francaise de Sécurité Sanitaire des Aliments, 69007 Lyon, France \\ d Institut für Tierzucht und Tierverhalten, Bundesforschungsanstalt für Landwirtschaft (FAL), \\ Dörnbergstr. 25-27, 29223 Celle, Germany
}

(Received 21 December 2000; accepted 16 February 2001)

\begin{abstract}
Besides their role as commensals on the skin and mucosal surfaces, staphylococci may be involved in a wide variety of diseases in animals. Staphylococcal infections in animals are mainly treated with antimicrobial agents and as a consequence, staphylococci from animal sources have developed and/or acquired resistance to the respective antimicrobial agents. Resistance statistics obtained from national monitoring programmes on staphylococci from cattle and pigs, but also from surveillance studies on staphylococci involved in diseases in dogs are reported and reviewed with regard to their comparability. This review mainly focusses on the genetic basis of antimicrobial resistance in staphylococci of animal origin. Particular attention is paid to resistance to those antimicrobial agents which are most frequently used in veterinary medicine, but also to antimicrobial agents, such as chloramphenicol and mupirocin, which are used in specific cases for the control of staphylococcal infections in pets and companion animals. In addition, plasmids and transposons associated with the respective resistance properties and their ways of spreading between members of the same or different staphylococcal species, but also between staphylococci and other gram-positive bacteria, are described.
\end{abstract}

antimicrobial resistance / Staphylococcus / animal origin / epidemiology / horizontal gene transfer

* Correspondence and reprints

Tel.: (49) 5141 384673; fax: (49) 5141 381849; e-mail: stefan.schwarz@fal.de 
Résumé - Résistance aux antimicrobiens chez les staphylocoques des animaux en particulier Staphylococcus aureus du bovin, $S$. hyicus du porc et $S$. intermedius du chien. Les staphylocoques sont des bactéries commensales de la peau et des surfaces des muqueuses, mais peuvent être impliqués dans une grande variété de maladies chez les animaux. Les infections à staphylocoques chez les animaux sont généralement traitées par des agents antimicrobiens avec pour conséquence le développement et/ou l'acquisition de résistance à ces agents. Une revue est faite à partir des statistiques de résistance issues des programmes nationaux de surveillance des staphylocoques chez les bovins et les porcs, et également des études de surveillance de cas cliniques chez le chien. Cette revue porte principalement sur les bases génétiques de la résistance des staphylocoques d'origine animale aux antibiotiques les plus fréquemment utilisés en médecine vétérinaire mais également à d'autres antibiotiques tels que le chloramphénicol et la mupirocine qui sont utilisés pour contrôler les infections à staphylocoques chez les animaux de compagnie. Cette revue décrit également le rôle de plasmides et de transposons dans la diffusion de la résistance aux antibiotiques entre staphylocoques d'une même espèce ou d'espèces différentes, mais également entre staphylocoques et d'autres bactéries à Gram-positif.

résistance aux antimicrobiens / staphylocoque / origine animale / épidémiologie / transfert horizontal de gène

\section{Table of contents}

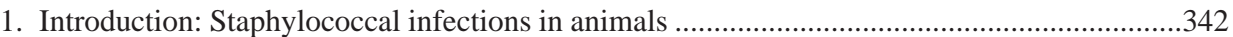

2. Epidemiology of antimicrobial resistance in staphylococci of animal origin ...........................343

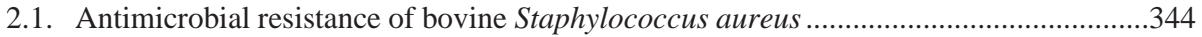

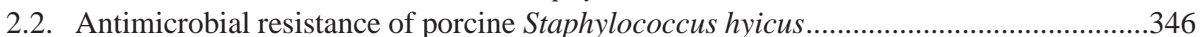

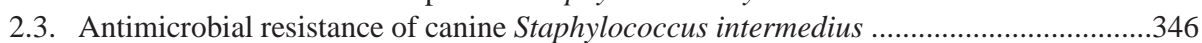

2.4. Antimicrobial resistance of coagulase-negative staphylococci from various

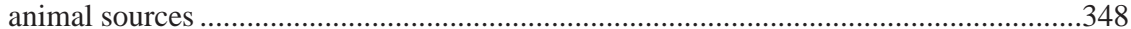

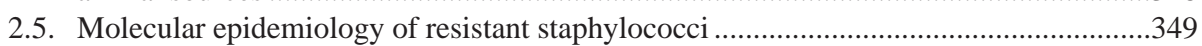

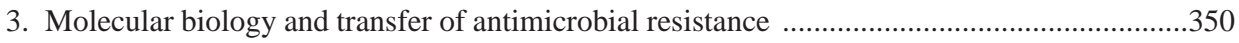

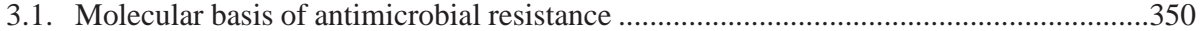

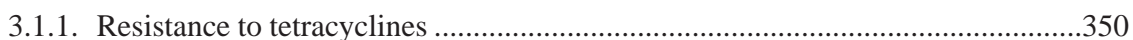

3.1.2. Resistance to macrolides, lincosamides, and streptogramins...............................351

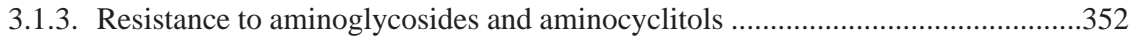

3.1.4. Resistance to chloramphenicol and florfenicol ...................................................353

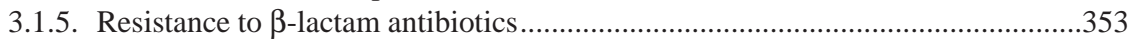

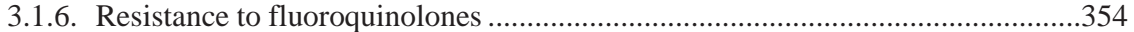

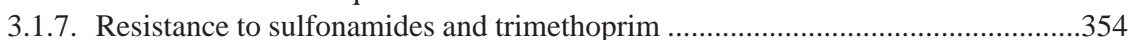

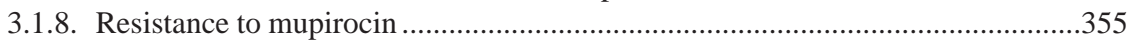

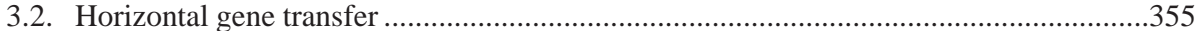

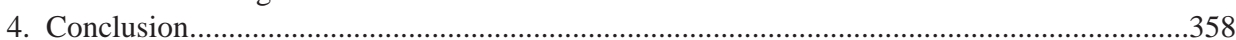

1. INTRODUCTION:

STAPHYLOCOCCAL INFECTIONS IN ANIMALS

Staphylococci are facultative anaerobic, gram-positive, catalase-positive cocci assigned to the family Micrococcaceae. They often represent part of the normal bac- terial flora of the skin and mucosal surfaces of the respiratory, upper alimentary and urogenital tract of mammals and birds. Thus staphylococci are easily spread between animals, and under certain conditions to humans as well by skin to skin contact, but also by contact with excretions which contain staphylococci, such as saliva, or aerosols 
released during sneezing and coughing. Moreover, staphylococci may be spread by animal products, such as non-pasteurised milk. When gaining entry into deeper tissues, e.g. as a consequence of scratch or bite wounds, burns, or ectoparasitic infestations, members of various staphylococcal species, including what are referred to as "potentially pathogenic", mostly coagulase-negative species, can cause a wide variety of usually pyogenic processes in different locations (e.g. skin, mammary gland, ears, joints, internal organs) in animals as well as in humans [9, 30]. In veterinary medicine, three of the 37 currently known staphylococcal species [21] are of particular importance as a primary cause of specific diseases: Staphylococcus $(S$.) aureus (mastitis in ruminants, equine botryomycosis), S. hyicus (porcine exudative epidermitis), and $S$. intermedius (canine pyoderma).

$S$. aureus causing mastitis is widely distributed in cattle, goats and sheep. The infection is often subclinical in cattle, leading to reduced milk production and milk quality, but acute catarrhal or even gangrenous inflammation may also occur. In goats and sheep however, enzootic acute gangrenous mastitis is commonly seen. S. hyicus causes exudative epidermitis ("greasy pig disease"), an often acute generalised skin infection in piglets. Systemic forms of the disease which result in the death of the animals are also seen. Poor hygienic conditions as well as ectoparasitic infestations favour the onset of the S. hyicus infection. Surviving piglets show retarded growth rates. In adult pigs, subacute skin infections, mastitis or metritis, but also septic arthritis may be caused by $S$. hyicus [9]. S. intermedius is considered the primary cause of canine and also feline pyoderma. Chronic and recurrent pyoderma - often seen in dogs - is considered a complex syndrome in which not only the staphylococci, but also cell-mediated hypersensitivity, endocrine disorders, and a genetic predisposition may play an important role in the development of the disease. In dogs and cats, S. intermedius has also been reported to be involved in other diseases, such as pyometra, otitis externa and purulent infections of the joints, eyelids and conjunctiva.

Antimicrobial agents of various classes are widely used for therapeutic intervention of diseases in animals caused by staphylococci, but also for prophylactic measures, e.g. for drying off dairy cows at the end of the lactation period. As a consequence, evolution in the frequency of staphylococci resistant to antimicrobial agents has been recorded over the last decades $[3,19,53$, 98]. This review presents data on the dissemination and the molecular biology of antibiotic resistance in staphylococcal isolates from animal sources, with particular reference to $S$. aureus, S. hyicus, and S. intermedius.

\section{EPIDEMIOLOGY OF ANTIMICROBIAL RESISTANCE IN STAPHYLOCOCCI OF ANIMAL ORIGIN}

Since the introduction of antimicrobials into human medicine, staphylococci have shown a frequent and rapid development and spread of antimicrobial resistance, particularly in nosocomial infections. Unfortunately, this development has not been documented continuously in the veterinary field. Publications differ distinctly in respect to the number of isolates and the staphylococcal species investigated, as well as the animal source, the clinical status of the animal, and the available information on antibiotic pretreatment. Moreover, different antimicrobial agents have been tested for their in vitro efficacy, and a variety of methods (disk diffusion, agar dilution, micro- and macrobroth dilution) as well as different standards for the interpretation of results (e.g. NCCLS documents M7-A5, M31-A, M37-A in the USA, DIN 58940 in Germany, CA-SFM in France) have been used.

Most of the studies deal with isolates of specific staphylococcal species or staphylococcal isolates of certain animal species 
obtained in restricted geographic locations and/or clinical situations, and therefore, the resulting data are only of limited value for epidemiological considerations. A good example of this is given in the review of Aarestrup and Jensen [1] on penicillin resistance in bovine $S$. aureus. In Europe, animal staphylococci are included in the national monitoring programmes of eight countries (Austria, Belgium, Denmark, France, Germany, the Netherlands, Portugal, and the UK), but the respective data are difficult to compare due to differences in probe sampling strategies, as well as in the methodology of resistance testing and evaluation.

\subsection{Antimicrobial resistance of bovine Staphylococcus aureus}

Because of its pathogenicity for both humans and animals, $S$. aureus has been the main subject of studies on antibiotic resistance in staphylococci [40]. In human medicine, antimicrobial multiresistance is frequently encountered and methicillin-resistant $S$. aureus strains (MRSA) are among the most threatening bacteria involved in nosocomial infections [7]. In veterinary medicine, however, MRSA, as well as multiresistant $S$. aureus strains, are reported only occasionally [18, 29, 93, 94, 100]. MRSA isolates detected in animal staphylococci have mostly been assumed to originate from human sources $[1,93]$.

S. aureus isolates from bovine mastitis have been the subject of numerous studies on antimicrobial resistance for the last 20 years. During the 1980 s, overall low resistance values were reported [17, 22, 23, $55,58]$. However, production of $\beta$-lactamase was frequently observed $[17,58]$.

Large scale studies on antimicrobial resistance of bovine $S$. aureus involving up to 5240 isolates per year conducted as part of the national monitoring programme in Germany during 1992-1997 revealed resistance to penicillin and ampicillin in 38-57\% of the isolates $[97,98]$, whereas resistance to oxacillin decreased from $16 \%$ in 1992 to $4 \%$ in 1997 . Resistance to tetracycline, kanamycin, neomycin and sulfonamides/ trimethoprim also decreased during this period and was detected in 1997 in usually less than $15 \%$ of the isolates tested (Tab. I).

Table I. Comparative analysis of antimicrobial resistance in bovine $S$. aureus isolates from different studies conducted between 1992 and 1999 [3, 32, 95] (data from Denmark and Germany, 1997, are cited from Fair Concerted Action PL97-3654, unpublished results).

\begin{tabular}{|c|c|c|c|c|c|}
\hline \multirow[t]{2}{*}{ Antimicrobial agents } & \multicolumn{5}{|c|}{ Numbers (percentages) of resistant bovine $S$. aureus isolates } \\
\hline & $\begin{array}{c}\text { Denmark } \\
1997 \\
(n=133)\end{array}$ & $\begin{array}{c}\text { Germany } \\
1997 \\
(n=15-4779)\end{array}$ & $\begin{array}{c}\text { Switzerland } \\
1992 \\
(n=63)\end{array}$ & $\begin{array}{c}\text { Brazil } \\
1999 \\
(n=66)\end{array}$ & $\begin{array}{c}\text { Denmark } \\
1998 \\
(n=269)\end{array}$ \\
\hline tetracycline & $5(3.8)$ & $473(9.9)$ & 0 & $8(12.1)$ & $3(1.1)$ \\
\hline penicillin & $35(26.3)$ & $2485(52.2)$ & $9(14.3)$ & $29(43.9)$ & $59(21.9)$ \\
\hline erythromycin & $4(3.0)$ & $456(11.4)$ & $2(3.2)$ & n.d. & n.d. \\
\hline linco-/clindamycin & $3(2.3)$ & $676(22.8)$ & $2(3.2)$ & $3(4.5)$ & n.d. \\
\hline streptomycin & $5(3.8)$ & $1155(29.3)$ & n.d. & $8(12.1)$ & $11(4.1)$ \\
\hline gentamicin & 0 & $1456(51.2)$ & 0 & 0 & 0 \\
\hline kanamycin & n.d. & $385(12.4)$ & n.d. & $8(12.1)$ & n.d. \\
\hline $\begin{array}{l}\text { sulfonamides } \\
\text { sulfonamides/ }\end{array}$ & $70(52.6)$ & $31(50.0)$ & $3(4.8)$ & n.d. & $57(21.2)$ \\
\hline trimethoprim & n.d. & $69(3.2)$ & n.d. & 0 & n.d. \\
\hline enrofloxacin & 0 & $165(10.1)$ & n.d. & n.d. & n.d. \\
\hline chloramphenicol & 0 & $2(13.3)$ & 0 & $1(1.5)$ & $4(1.5)$ \\
\hline
\end{tabular}


Table II. Numbers (percentages) of susceptible coagulase-positive and coagulase-negative bovine staphylococci observed in France during the periods 1990-1993 [42] and 1994-2000 (Martel, unpublished data from RESABO).

\begin{tabular}{|c|c|c|c|c|c|c|}
\hline \multirow[t]{2}{*}{$\begin{array}{l}\text { Antimicrobial } \\
\text { agents }\end{array}$} & \multicolumn{2}{|c|}{$\begin{array}{l}\text { Breakpoints for } \\
\text { sensitivity* }\end{array}$} & \multicolumn{2}{|c|}{$\begin{array}{l}\text { Numbers (percentages) } \\
\text { of susceptible coagulase- } \\
\text { positive staphylococci }\end{array}$} & \multicolumn{2}{|c|}{$\begin{array}{l}\text { Numbers (percentages) } \\
\text { of susceptible coagulase- } \\
\text { negative staphylococci }\end{array}$} \\
\hline & $\begin{array}{c}\text { MIC } \\
\left(\mu \mathrm{g} \cdot \mathrm{mL}^{-1}\right)\end{array}$ & $\begin{array}{l}\text { Diameter } \\
(\mathrm{mm})\end{array}$ & $\begin{array}{c}1990-1993 \\
\text { n }(12-343)\end{array}$ & $\begin{array}{c}1994-2000 \\
\text { n }(59-387)\end{array}$ & $\begin{array}{c}1990-1993 \\
\text { n }(9-47)\end{array}$ & $\begin{array}{l}1994-2000 \\
\text { n }(17-98)\end{array}$ \\
\hline penicillin & 0.25 & 29 & $109(36.0)$ & $197(51.0)$ & $14(37.8)$ & $50(56.2)$ \\
\hline oxacillin & 2 & 20 & $12(100)$ & 205 (98.1) & $2(22.2)$ & $51(89.5)$ \\
\hline streptomycin & 8 & 15 & $226(72.0)$ & 145 (61.2) & $19(73.1)$ & $64(81.0)$ \\
\hline kanamycin & 8 & 17 & $163(94.8)$ & $123(98.4)$ & $8(88.9)$ & $23(92.0)$ \\
\hline gentamicin & 4 & 16 & $336(99.1)$ & 333 (99.1) & $27(61.4)$ & $91(93.8)$ \\
\hline tetracycline & 4 & 19 & $293(88.0)$ & 367 (95.1) & $27(57.4)$ & $73(74.5)$ \\
\hline erythromycin & 1 & 22 & $186(79.8)$ & $222(82.8)$ & $9(30.0)$ & $55(77.5)$ \\
\hline lincomycin & 2 & 21 & $161(91.0)$ & $189(96.0)$ & $16(57.1)$ & $55(75.3)$ \\
\hline \multirow{2}{*}{$\begin{array}{l}\text { chloramphenicol } \\
\text { sulfamethoxazole- } \\
\text { trimethoprim }\end{array}$} & 8 & 23 & $182(53.1)$ & 59 (100) & $21(56.8)$ & $12(70.6)$ \\
\hline & $38 / 2$ & 16 & $225(95.0)$ & $329(99.1)$ & $16(66.7)$ & $79(93.0)$ \\
\hline
\end{tabular}

* Breakpoints according to CA-SFM.

A comparison of the data from the French national monitoring programme (RESABO), obtained from the periods 1990-1993 and 1994-2000 on coagulase-positive and coagulase-negative staphylococci (CNS) of bovine origin recorded an overall decline in resistance. For almost all antibiotics tested, increasing numbers of susceptible bovine staphylococci were seen in the period 1994-2000 (Tab. II). In the Rhône-Alpes Region of France where cheese production using non-pasteurized milk is important, the necessity to monitor sub-clinical infections has revealed the role of the coagulase-negative staphylococci. A study showed that CNS were less susceptible to antimicrobial agents than coagulase-positive staphylococci [59]. This observation was also confirmed by the data from the RESABO programme during the last decade (Tab. II). During the past 10 years, a decrease in staphylococcal resistance to antimicrobial agents was observed which could be due to two very important changes: the widespread use of oxacillin and cloxacillin and dry cow therapy. A similar observation was made in a 25-year survey in Belgium [19].
In Switzerland, approximately $14 \%$ of the $S$. aureus isolates from cases of bovine mastitis showed resistance to penicillin, while only $5 \%$ were resistant to sulfonamides and 3\% to macrolides and lincosamides, respectively [95] (Tab. I). In Denmark, about half of the isolates studied showed resistance to sulfonamides and a quarter of the isolates was resistant to penicillin, while resistance to other antimicrobials frequently used in veterinary medicine was not recorded at all or only at very low levels (Tab. I) [1]. Beyond the situation in Denmark, Aarestrup and Jensen [1] gave a review about publications dealing with resistance to penicillin and concluded that most of the published results are difficult to compare, but seem to show an increasing penicillin resistance rate at least in some countries. In a study from the USA, minimal inhibitory concentration (MIC) values for different $\beta$-lactam antibiotics were determined and thereby some methicillin-resistant strains were detected [94]. Bovine S. aureus isolates from Brazil varied in their penicillin resistance rates between 20 and $100 \%$, but in accordance with the previously described 
publications, revealed low levels of resistance to other antimicrobials $[32,57]$. An overall low level of resistance with, however, $57 \%$ of the isolates showing $\beta$-lactamase activity was recorded in a large scale study on $811 \mathrm{~S}$. aureus strains from bovine mastitis obtained in nine European countries, the USA and Zimbabwe [18].

Based on these observations, bovine S. aureus can still be treated effectively with the usual set of antibiotics available for use in food-producing animals, even though the frequent occurrence of penicillin resistance should be considered when choosing the most suitable antimicrobial agent for therapeutic applications. Preference should be given to antimicrobials other than penicillin when $\beta$-lactamase-producing isolates are involved.

\subsection{Antimicrobial resistance of porcine Staphylococcus hyicus}

S. hyicus infections are of considerable importance for pig breeders and although autogenous vaccines are sometimes used, antimicrobial therapy is most frequently applied in acute outbreaks of the disease. Nevertheless, relatively few data on resistance in S. hyicus are available.

The Danish monitoring programme DANMAP is currently the only national monitoring programme worldwide which gives representative data on the resistance situation in S. hyicus isolates from pigs. In the DANMAP 1999 [3] monitoring programme (available on the internet at http:// www.svs.dk), approximately $75 \%$ of the $S$. hyicus isolates were resistant to penicillin, $36 \%$ to streptomycin, $24 \%$ to tetracycline, $22 \%$ to trimethoprim and $15 \%$ to erythromycin, while resistance to other antibiotics tested was negligible. As compared to data from DANMAP 1998, this represented a decline in resistance to erythromycin, streptomycin, trimethoprim and sulfonamides. Noble and Allaker [49] studied antimicrobial resistance in isolates of various staphy- lococcal species obtained from pigs of two British farms with different antibiotic usage policies. They identified an epidemic $S$. hyicus strain mediating resistance to penicillin, tetracycline, erythromycin, lincomycin, streptomycin, and chloramphenicol. Plasmids of this and other multiresistant $S$. hyicus strains were analysed in some detail in a number of different studies (see chapter 3) and it became obvious that the resistance plasmids identified in S. hyicus did not always correspond structurally to the respective plasmids known in human staphylococci [51, 63, 77, 78, 81, 82]. In 1993, Wegener and Schwarz compared antibiotic resistances of $S$. hyicus isolates from diseased and healthy pigs [101]. A number of small plasmids carrying antibiotic resistance genes were detected (see Chapter 3). In particular, a plasmid of $11.5 \mathrm{kbp}$, mediating tetracycline and macrolide/lincosamide resistance [87], was found more often in isolates from diseased pigs, but genes coding for virulence factors were not found to be located on this plasmid. The investigation of $100 \mathrm{~S}$. hyicus isolates for their MIC values of 13 different antimicrobial agents identified novobiocin as the most active compound tested, followed by enrofloxacin, ampicillin and ceftiofur [102].

The overall resistance rates of porcine S. hyicus isolates as summarised in Table III are distinctly higher than those of $S$. aureus isolates from bovine mastitis. The reason for this may - at least in part - be related to a higher level of antibiotic use in pigs, not necessarily always for the treatment of porcine exudative epidermitis, but also for the control of respiratory and gastrointestinal infections, and may also be related to the use of antibiotics (mainly macrolides) in former times for growth promotion.

\subsection{Antimicrobial resistance of canine Staphylococcus intermedius}

S. intermedius isolates from canine and feline pyogenic infections have been reported to be frequently resistant to more 
Table III. Comparative analysis of antimicrobial resistance in porcine $S$. hyicus isolates from different studies conducted between 1988 and 1997 in the UK [49], Denmark [101], and Germany [70] (data from Denmark and Germany, 1997, are cited from Fair Concerted Action PL97-3654, unpublished results).

\begin{tabular}{|c|c|c|c|c|c|}
\hline \multirow[t]{2}{*}{ Antimicrobial agents } & \multicolumn{5}{|c|}{ Numbers (percentages) of resistant porcine $S$. hyicus isolates } \\
\hline & $\begin{array}{c}\text { UK } \\
1988 \\
(n=37)\end{array}$ & $\begin{array}{c}\text { Germany } \\
1989 \\
(n=32)\end{array}$ & $\begin{array}{c}\text { Denmark } \\
1992 \\
(n=100)\end{array}$ & $\begin{array}{c}\text { Denmark } \\
1997 \\
(n=90)\end{array}$ & $\begin{array}{c}\text { Germany } \\
1997 \\
(n=34-71)\end{array}$ \\
\hline tetracycline & $15(40.5)$ & $21(65.6)$ & $47(47.0)$ & $26(28.9)$ & $46(66.7)$ \\
\hline penicillin & $12(32.4)$ & $8(25.0)$ & $44(44.0)$ & $56(62.2)$ & $42(59.2)$ \\
\hline erythromycin & $4(10.8)$ & $1(3.1)$ & $59(59.0)$ & $57(63.3)$ & $27(41.5)$ \\
\hline linco-/clindamycin & $4(10.8)$ & $1(3.1)$ & $59(59.0)$ & $59(65.6)$ & $37(59.7)$ \\
\hline streptomycin & $19(51.4)$ & $14(42.8)$ & $56(56.0)$ & $41(45.5)$ & $32(68.1)$ \\
\hline gentamicin & 0 & n.d. & 0 & 0 & $27(39.7)$ \\
\hline kanamycin & n.d. & $1(3.1)$ & $15(15.0)$ & n.d. & $18(51.4)$ \\
\hline $\begin{array}{l}\text { sulfonamides } \\
\text { sulfonamides/ }\end{array}$ & n.d. & $32(100)$ & n.d. & $23(25.5)$ & $22(57.9)$ \\
\hline trimethoprim & n.d. & n.d. & 0 & n.d. & $18(26.5)$ \\
\hline enrofloxacin & n.d. & n.d. & 0 & $5(5.6)$ & $9(13.2)$ \\
\hline chloramphenicol & 0 & $3(9.4)$ & 0 & 0 & $3(8.8)$ \\
\hline
\end{tabular}

Table IV. Comparative analysis of antimicrobial resistance in canine $S$. intermedius isolates from different studies conducted between 1986 and 1995 in the USA [46], the UK [50], Denmark [56], and USA/Germany [25].

\begin{tabular}{lcccc}
\hline Antimicrobial agents & \multicolumn{3}{c}{ Numbers (percentages) of resistant canine $S$. intermedius isolates } \\
\cline { 2 - 5 } & $\begin{array}{c}\text { USA 1986 } \\
(n=197)\end{array}$ & $\begin{array}{c}\text { UK 1992 } \\
(n=96)\end{array}$ & $\begin{array}{c}\text { USA/Germany 1992 } \\
(n=116)\end{array}$ & $\begin{array}{c}\text { DK 1995 } \\
(n=50)\end{array}$ \\
\hline tetracycline & $104(52.8)$ & $50(52.1)$ & $35(30.0)$ & $10(20.0)$ \\
penicillin & $163(82.7)$ & $77(80.2)$ & n.d. & $30(60.0)$ \\
erythromycin & $52(26.4)$ & $9(9.4)$ & $15(12.9)$ & n.d. \\
linco-/clindamycin & $49(24.9)$ & n.d. & $15(12.9)$ & n.d. \\
streptomycin & n.d. & $6(6.3)$ & $27(23.3)$ & n.d. \\
gentamicin & 0 & n.d. & $1(0.9)$ & n.d. \\
sulfonamides/ & $17(8.6)$ & n.d. & n.d. & 0 \\
trimethoprim & n.d. & n.d. & n.d. & 0 \\
enrofloxacin & n.d. & $7(6.0)$ & $8(16.0)$ \\
chloramphenicol & $21(10.7)$ & & & \\
\hline
\end{tabular}

than one antibiotic. A comparison of data on antimicrobial resistance in canine $S$. intermedius isolates is shown in Table IV.

A study from the USA documented resistance rates in a large number of $S$. aureus and $S$. intermedius isolates from dogs between 1977 and 1983 [16]. Sensitivity was generally high (more than $80 \%$ ), with the exception of penicillin/ampicillin (approximately 50\% resistant strains, resistance slightly decreasing). About 60-70\% of the isolates were sensitive to streptomycin, tetracyclines, sulfonamides and polymyxin $B$, but the numbers of resistant isolates were increasing. Another study from the USA deals with canine $S$. intermedius and the comparison of disk diffusion test- 
ing versus MIC determination [60]. In accordance with the latter publication, only penicillin/ampicillin and tetracycline resistance rates were higher than 20\% (approximately $55 \%$ and $35 \%$, respectively). Resistance to methicillin, cephalothin and gentamicin could not be detected. In addition, it was observed that all multiresistant strains produced $\beta$-lactamase and it was assumed, but not proven, that the resistance determinants may be plasmid-localised. A third study [46] revealed similar results, but the penicillin resistance rate was even higher $(83 \%)$. Furthermore, resistance against chloramphenicol and macrolide/lincosamides seemed to increase with the use of these antibiotics.

A British study from 1992 [50] again confirmed these findings with resistance rates of $80 \%$ for penicillin and $50 \%$ for tetracycline, but low percentages of resistant isolates for the remaining antibiotics tested. An increase in resistance was recorded after therapeutic application of the respective antibiotics. Moreover, plasmid profiles were determined and it was observed that - in contrast to a previous report from $S$. hyicus [49] - only small numbers of plasmids could be found in S. intermedius. The same observation was made by Greene and Schwarz [25], who investigated $S$. intermedius isolates from the USA and Germany for the presence of plasmids involved in antimicrobial resistance. Another publication from the UK [36] reported resistance rates in a large number of pathogenic canine staphylococci, mainly $S$. intermedius and $S$. aureus, during a 16-year-period between 1980 and 1996. Again, previous results were confirmed: penicillin resistance increased from approximately 70 to $90 \%$, tetracycline resistance remained at about $40 \%$ and resistance to other antibiotics remained at low levels.

In summary, resistance to penicillin and tetracycline is frequently seen and increasing in canine $S$. intermedius isolates of different geographic origins, whereas resistance to most other antibiotics, particularly to newer antimicrobial agents, such as the fluoroquinolones, is to date still compara- tively low. However, it should be noted that the antimicrobials available for the treatment of pets and companion animals represent a much larger selection of substances than those available for food-producing animals, and resistance rates may also increase in staphylococci from companion animals with the frequent use of a certain substance.

\subsection{Antimicrobial resistance of coagulase-negative staphylococci from various animal sources}

Coagulase-negative staphylococci can also be associated with diseases in humans and animals. A review on antimicrobial resistance in CNS (mainly S. epidermidis) from humans was published by Archer and Climo [6]. CNS are an increasing problem in nosocomial infections and it was stated that this may be due to the increase of multiresistant CNS isolates.

In veterinary medicine, CNS from bovine mastitis were investigated in the USA [96] and France [43]. In the study from the USA, $S$. chromogenes was the most often isolated staphylococcal species, showing resistance rates of approximately $30 \%$ for penicillin/ampicillin, $12 \%$ for streptomycin and more than $80 \%$ for sulfonamides. Low numbers of CNS isolates resistant to tetracycline, kanamycin, nitrofurantoin, and novobiocin were determined. In contrast, in the French study, S. xylosus occurred most frequently, with $S$. epidermidis in second place. In $S$. xylosus, only resistance to novobiocin and a few strains with elevated MIC values for erythromycin and chloramphenicol were reported, but most of the isolates were susceptible to all antimicrobials tested. In S. epidermidis, however, considerable numbers of isolates which exhibited resistances to tetracycline, gentamicin, kanamycin, ampicillin and even oxacillin were reported. In their paper about staphylococci on the skin of pigs, Noble and Allaker [49] described that tetracycline resistance was most frequently observed in isolates of various CNS 
species, followed by macrolide/lincosamide resistance. The results could be explained by the prophylactic use of these compounds on the respective farm.

A number of studies have been published on resistance in staphylococci from poultry. Aarestrup et al. [4] recently reported resistance rates and the corresponding genes in S. aureus and CNS from poultry. They frequently found resistance to fluoroquinolones, tetracyclines, and macrolides, whereas resistances to other antimicrobials tested were detected at very low frequencies. Other studies [29, 47] focussed on the analysis of specific resistance properties in avian staphylococci, such as macrolide resistance in avian coagulase-positive staphylococci and CNS or methicillin resistance in CNS from chickens. In the latter study, approximately $25 \%$ of all isolates were methicillin-resistant and a majority of them, mainly $S$. sciuri, were investigated for their epidemiological relationship. Most of the isolates were confirmed by pulsed-field gel electrophoresis to have a clonal origin.

For pets and companion animals, antimicrobial resistance rates from the skin and saliva of healthy cats have been determined [34]. The most common staphylococcal species was $S$. felis of which 20 of the 33 isolates investigated were resistant to 1-5 antimicrobials tested and resistance was frequently observed. Resistance to penicillin $(57.6 \%)$ and tetracycline $(33.3 \%)$ was predominantly encountered among the $S$. felis isolates [33]. A study on staphylococci from rabbits identified $S$. sciuri as the predominant species [28]. Of the 38 leporine $S$. sciuri isolates studied, only a single isolate was resistant to chloramphenicol and tetracycline while another isolate was resistant to tetracycline only. All remaining 36 isolates were sensitive to all antimicrobials tested.

In short, reports about CNS are limited and vary largely in the given details on the isolates tested and the methodology applied. Thus the comparability of the data obtained from these reports is low. Nevertheless, such reports represent a complement to the often more detailed studies on coagulase-positive staphylococci from animals and may reflect at least the resistance situation for CNS obtained from specific animal species in restricted geographic areas.

\subsection{Molecular epidemiology of resistant staphylococci}

Various methods for the differentiation of resistant staphylococci have been established and allow to distinguish between staphylococcal isolates of the same species and subspecies [107]. The typing methods, however, differ in their discriminatory power and in their applicability. Methods which are applicable to isolates of virtually all staphylococcal species of humans and animals include biochemical methods, e.g. multilocus enzyme electrophoresis and molecular methods such as macrorestriction analysis, ribotyping, rRNA spacer typing as well as RAPD-PCR. Among these methods, macrorestriction analysis using the restriction enzyme SmaI is considered to have the highest discriminatory power [107]. Certain PCR-based typing methods also refer to genes which are present only in specific staphylococcal species, e.g. S. aureus. These methods include the detection of polymorphisms in the genes coding for coagulase (coa) or protein A (spa) $[32,107]$. Moreover, methods which are based on the presence of sequences associated with certain transposons such as tar916-shida-PCR (Tn916) or inter-IS256-PCR (Tn4001) may be suitable for the differentiation of tetracycline or gentamicin-kanamycintobramycin resistant isolates which carry the respective transposons, but may be of limited value for the differentiation of isolates which do not harbour these transposons [107]. In certain staphylococcal species such as $S$. aureus, S. epidermidis or S. sciuri, an extended analysis of the biochemical capacities as obtained from the species differentiation by using the ID32 Staph system 
(BioMérieux, Lyon, France) may also provide helpful information for a differentiation of single isolates [28, 32]. Plasmid profiling is also a fast and simple typing method, but it often does not generate stable results due to the mobility of plasmids. Since resistance properties in staphylococci are often associated with plasmids, plasmid analysis may be useful for studies on the transferability of certain resistance properties, but is not a suitable method for the differentiation of resistant isolates.

The determination of epidemiological relationships of resistant staphylococcal isolates is of particular importance for the differentiation between a clonal spread of a certain resistant or multiresistant isolate and the horizontal spread of a certain resistance gene - mostly located on a plasmid or a transposon - between different isolates. In contrast to human medicine where molecular typing methods are routinely used to follow the spread of MRSA clones and other staphylococci involved in nosocomial infections, such methods are mainly used in the veterinary field to differentiate $S$. aureus isolates from bovine mastitis [2, 32]. However, in view of their overall low resistance rates, the molecular differentiation of such isolates is mostly for epidemiological purposes and not for the analysis of resistant isolates.

\section{MOLECULAR BIOLOGY AND TRANSFER OF ANTIMICROBIAL RESISTANCE}

\subsection{Molecular basis of antimicrobial resistance}

Knowledge of the molecular background of antimicrobial resistance in staphylococci has increased immensely during the last years. However, most publications deal with strains isolated from humans and relatively little is still known about antimicrobial resistance genes of animal staphylococci. The genes or mutations known so far which are involved in antimicrobial resistance of staphylococci from animal sources have been identified using molecular detection systems including PCR analysis or Southern blot hybridisation with specific gene probes. In selected cases the respective resistance genes, including their regulatory regions, have been cloned and sequenced. The resistance genes encountered in animal staphylococci are frequently found on plasmids. Thus structural analyses of the resistance plasmids have also been conducted and provide insight into the structural variety of extrachromosomal elements associated with antimicrobial resistance in animal staphylococci.

\subsubsection{Resistance to tetracyclines}

To date, four different tetracycline resistance (tet) genes assigned to classes $\mathrm{K}, \mathrm{L}, \mathrm{M}$, and $\mathrm{O}$ of bacterial tet genes have been detected in staphylococci of animal origin [91].

The tet $(\mathrm{K})$ genes are commonly located on small multicopy plasmids of 4.3 to $4.7 \mathrm{kbp}$ which are structurally closely related and do not harbour additional resistance genes $[25,68,72,78,84,91]$. The prototype tet $(\mathrm{K})$-encoding plasmid is the $4.45 \mathrm{kbp}$ plasmid pT181 from human S. aureus [40]. Plasmids indistinguishable from or closely related to pT181 have been detected in virtually all staphylococcal species of animal origin [25, 68, 72, 78, 84, 91, 105]. In rare cases pT181-like plasmids have also been detected as IS257-flanked integrates in the chromosome of $S$. aureus or as parts of large staphylococcal plasmids [105].

The tet $(\mathrm{L})$ genes were originally detected in the Bacillus species. Their presence in staphylococci seems to be limited to a few staphylococcal species of animal origin, such as $S$. aureus, $S$. hyicus, S. lentus, S. sciuri, and $S$. xylosus [91]. The tet(L) genes were mainly found on plasmids that varied in size between 4.3 and $11.5 \mathrm{kbp}$ [78, 87, 89]. As a consequence of co-integrate formation and recombination events with other resistance plasmids [89], but also due to the integration of small transposons [87], some of these tet $(\mathrm{L})$-carrying plasmids harbour additional antibiotic resistance genes. Such 
genes include the kanamycin/neomycin resistance gene $a a d D$ or the Tn917-borne macrolide-lincosamide-streptogramin B $\left(\mathrm{MLS}_{\mathrm{B}}\right)$ resistance gene erm(B) [78]. Expression of tet $(\mathrm{K})$ and $\operatorname{tet}(\mathrm{L})$ genes is inducible by tetracycline via translational attenuation [40, 87]. The tet $(\mathrm{K})$ and $\operatorname{tet}(\mathrm{L})$ gene products represent structurally related membrane-associated efflux systems consisting of 14 transmembrane segments. They prevent intracellular tetracycline (Tc) accumulation by an energy-dependent export of the drugs [64]. Both proteins confer resistance to all tetracyclines currently used for clinical and veterinary purposes, with the exception of minocycline.

The tet $(\mathrm{M})$ genes are commonly located on conjugative transposons of enterococcal origin, such as Tn916 or Tn1545 [64]. A study of 227 Tc-resistant staphylococci obtained from various animal sources identified $\operatorname{tet}(\mathrm{M})$ genes to be the second most prevalent tet genes in animal staphylococci; Tc resistance in $S$. intermedius was almost exclusively based on the presence of $\operatorname{tet}(\mathrm{M})$ genes [80,91].

The tet $(\mathrm{O})$ gene has so far only been detected in a single $S$. intermedius isolate and in combination with a $\operatorname{tet}(\mathrm{L})$ gene in a single $S$. xylosus isolate [91]. The tet $(\mathrm{M})$ and $\operatorname{tet}(\mathrm{O})$ gene products represent ribosome protective proteins which mediate resistance to all tetracyclines including minocycline.

\subsubsection{Resistance to macrolides, lincosamides, and streptogramins}

Staphylococcal resistance to antimicrobial agents of the classes macrolides, lincosamides and streptogramins is commonly based on either target-site modification, active efflux, or enzymatic inactivation [79]. Target modification is the most widespread resistance mechanism and refers to the dimethylation of an adenine residue in the 23S rRNA. Four rRNA methylase $(\mathrm{erm})$ genes, designated erm(A), erm(B), erm(C), and $\operatorname{erm}(\mathrm{F})$, have until now been identified in staphylococci of animal origin $[14,20$, 27, 38, 39, 73, 85, 90, 103, 104, 106].

The $\operatorname{erm}(\mathrm{A})$ and $\operatorname{erm}(\mathrm{B})$ genes are commonly found on small non-conjugative transposons, such as Tn554 and $\operatorname{Tn} 917 / \operatorname{Tn} 551$ [40], however, plasmid locations have also been detected in rare cases [103, 104]. The $\operatorname{erm}(\mathrm{C})$ genes are located on small multicopy plasmids of $2.3-4.0 \mathrm{kbp}$ which are present in many different staphylococcal species [38, 39, 73, 85, 90, 106]. Expression of the erm(A-C) genes can be inducible by 14-membered macrolides or constitutive [106]. Inducible $\mathrm{erm}$ gene expression results in resistance to 14-membered macrolides only while constitutively expressed $\mathrm{erm}$ genes confer resistance to 14-, 15- and 16-membered macrolides, lincosamides and streptogramin B antibiotics. Inducible expression of the $\operatorname{erm}(\mathrm{C})$ and $\operatorname{erm}(\mathrm{A})$ genes occurs via translational attenuation and requires an intact regulatory region consisting of two pairs of inverted repeated sequences as well as an open reading frame for a small peptide. So far, point mutations $[90,103]$, deletions $[39,106]$, or duplications $[38,106]$ of parts of this regulatory region have been identified to cause an irreversible switch from the inducible to the constitutive type of $\operatorname{erm}(\mathrm{C})$ or $\operatorname{erm}(\mathrm{A})$ gene expression. The $\operatorname{erm}(\mathrm{B})$ regulatory region also comprises a reading frame for a small peptide and a large number of pairs of inverted repeated sequences whose complex interplay is still not fully understood. The $\operatorname{erm}(\mathrm{F})$ gene which was originally identified on conjugative transposons from $\mathrm{Bac}$ teroides spp. is constitutively expressed [14].

Studies of the occurrence of the different erm genes among animal staphylococci $[14,20,27]$ showed that $\operatorname{erm}(\mathrm{C})$ genes were frequently seen in S. hyicus and other porcine staphylococci $[20,27]$, but also in many staphylococcal species from various animal sources [38, 39, 73, 85, 90, 106] while $\operatorname{erm}(\mathrm{B})$ genes were the dominant erm genes in canine $S$. intermedius isolates $[8,20]$. Genes of the class $\operatorname{erm}(\mathrm{F})$ have so far only been detected in a few S. intermedius iso- 
lates from pigeons [14] and $\operatorname{erm}(\mathrm{A})$ genes have also only been identified in single animal staphylococcal isolates, mainly of avian origin [47, 103] and porcine origin [27]. In rare cases, two different erm genes were present in the same staphylococcal isolate [20].

Active efflux systems as encoded by $m s r(\mathrm{~A})$ mediate resistance to 14 - and 15-membered macrolides as well as to type B streptogramins only. The $\operatorname{msr}(\mathrm{A})$ gene has rarely been detected in animal staphylococci, but has been reported to be the second most prevalent macrolide resistance gene in staphylococci of human origin [20]. A combination of $\operatorname{erm}(\mathrm{C})$ and $m \operatorname{sr}(\mathrm{A})$ has been described in a single porcine staphylococcal isolate [20]. The genes $v g a(\mathrm{~B})$ coding for a streptogramin A transporter and vat(B) coding for a streptogramin A acetyltransferase have recently been identified in two $S$. xylosus isolates from poultry [4].

\subsubsection{Resistance to aminoglycosides and aminocyclitols}

Resistance to aminoglycosides is mainly due to inactivation of the drugs by the acetyl-, adenyl (nucleotidyl)- or phosphotransferases, the genes of which are often found to be associated with plasmids and/or transposons [5, 79]. Aminocyclitols, such as spectinomycin, are commonly inactivated by adenyltransferases. The nomenclature of the genes involved in aminoglycoside and aminocyclitol resistance has been the subject of frequent changes $[5,79]$. Four different genes have been identified so far in animal staphylococci.

The gene $a a d D$, also known as ant(4')-Ia or $\operatorname{aad}\left(4^{\prime}\right)\left(4^{\prime \prime}\right)$, mediates resistance to kanamycin and neomycin. It is located on the $4.5 \mathrm{kbp}$ plasmid pUB110 [45]. The $5.5 \mathrm{kbp}$ plasmid pSTS7 obtained from a porcine isolate of $S$. epidermidis carried a pUB110-analogous aadD gene in addition to a $\operatorname{tet}(\mathrm{L})$ tetracycline resistance gene [89]. Sequence analysis of the flanking regions of both resistance genes led to the development of a model according to which plasmid pSTS7 arose from the interplasmidic recombination between two incompatible aadD- and tet $(\mathrm{L})$-carrying plasmids [89]. A plasmid indistinguishable from pSTS7 in its restriction map and also mediating resistances to kanamycin, neomycin and tetracycline has subsequently been detected in a porcine $S$. hyicus isolate as well [Schwarz, unpublished data]. Gene str coding for an adenyltransferase which confers resistance only to streptomycin has been detected on plasmid pS194 [62]. Small plasmids of approximately $4.5 \mathrm{kbp}$ which closely resemble pS194 in their restriction maps have been detected in porcine isolates of S. hyicus [71], but also in $S$. warneri isolates of feline and avian origin as well as in $S$. lentus isolates from pigeons (Schwarz and Werckenthin, unpublished data). A pS194-like str gene was also detected on naturally occurring plasmids from porcine $S$. hyicus and bovine $S$. sciuri which confer chloramphenicol and streptomycin resistance [76, 77].

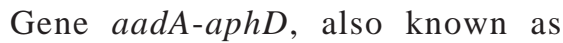
$\operatorname{aac}\left(6^{\circ}\right)-\operatorname{aph}\left(2^{\prime \prime}\right)$, codes for a bifunctional enzyme with acetyl- and phosphotransferase activity which mediates combined resistance to gentamicin, kanamycin and tobramycin. This gene is associated with the composite transposon Tn4001 [65] which is frequently found on conjugative plasmids in enterococci. Plasmid and chromosomal locations of this transposon in staphylococci have been determined as the result of conjugative transfer events between enterococci and S. aureus, S. intermedius and S. hyicus isolates [52]. More recently, Tn4001-like elements in which IS256 was structurally deleted by the insertion of copies of IS257 were detected on conjugative and non-conjugative plasmids in avian isolates of $S$. sciuri and $S$. warneri [31]. Despite the differences in the terminal regions of the Tn4001-like elements, the aacA-aphD genes were identical to that of Tn4001 [31].

In $S$. intermedius isolates from pets, Tn5404-like elements carrying the genes aphA-3 (also referred to as $a p h\left(3^{\prime}\right)$-IIIa), sat4, and $a a d E$ (also referred to as ant(6)-Ia) the products of which code for resistances to 
kanamycin/neomycin, streptothricin, and streptomycin, respectively, were detected [8]. These elements were physically linked to the $\mathrm{MLS}_{\mathrm{B}}$ resistance gene erm(B) [8].

Gene $s p c$, also referred to as ant(9)-Ia or $\operatorname{aad}(9)$, codes for an adenyltransferase which confers resistance to the aminocyclitol antibiotic spectinomycin. This resistance gene is part of the non-conjugative transposon Tn554 which also harbours an erm(A) gene and has so far been found in staphylococci from animals only in connection with this gene.

\subsubsection{Resistance to chloramphenicol and florfenicol}

Chloramphenicol resistance in staphylococci is commonly due to the inactivation of the drug by plasmid-borne chloramphenicol acetyltransferases of type A (CatA) [5]. Native CatA is a trimer composed of three identical monomers. The catA gene carries the genetic information for one monomer. Until now, three families of staphylococcal catA genes are known and named according to the plasmids pC221, pC223 and pC194 on which they have been detected [40]. The expression of all known staphylococcal catA genes is inducible by $\mathrm{Cm}$ via translational attenuation [40]. Only plasmids of the pC221- and the pC223-family have been isolated from staphylococci of animal origin [10, 12, 69, 74-77, 81, 83, 84, $86,88]$. With the exception of plasmid pSCS5 from $S$. haemolyticus [74], plasmids of the pC223-family are structurally closely related repJ-based replicons of 4.5-4.6 kbp $[11,69,75,88]$. In contrast, plasmids of the pC221-family share only the rep $\mathrm{D} /$ cat region which is flanked by the recombination site $\mathrm{B}$ and the palindromic sequence palA as well as by the cat gene transcriptional terminator. These structural elements are considered to play a role in interplasmidic recombinations leading to a wide variety of plasmids carrying a common rep $\mathrm{D} /$ catA region. $\mathrm{Cm}$ resistance plasmids of the pC221-family vary in size from
2.9-5.1 kbp and occasionally carry a streptomycin $(\mathrm{Sm})$ resistance gene. Two naturally occurring $\mathrm{Cm} / \mathrm{Sm}$ resistance plasmids have been detected in animal staphylococci, one in a bovine $S$. sciuri [76] and the other in a porcine $S$. hyicus [77]. Both plasmids are believed to have developed by sitespecific recombination processes between a pC221-like $\mathrm{Cm}$ resistance plasmid and a pS194-analogous Sm resistance plasmid $[76,77]$. Comparative data on the catA gene and its gene product are only available for the determinants located on plasmids pC221 and pSCS6 of the pC221-family and plasmids pSCS5 and pSCS7 of the pC223 family $[10,12,74,75]$.

Neither $c a t A$ nor $c a t B$ genes are involved in resistance to the fluorinated $\mathrm{Cm}$ derivative florfenicol. Combined resistance to chloramphenicol and florfenicol mediated by efflux systems has been described in gramnegative bacteria. Recently a novel gene, $c f r$, which mediates resistance to chloramphenicol and florfenicol has been identified on a plasmid from a bovine $S$. sciuri isolate [92]. The $c f r$ gene product neither exhibits topology of a membrane protein nor inactivates chloramphenicol and florfenicol. So far, florfenicol-resistant staphylococci have been detected very rarely.

\subsubsection{Resistance to $\beta$-lactam antibiotics}

Penicillin resistance is widespread in animal staphylococci, but methicillin resistance remains a rather rare finding. Resistance to $\beta$-lactam antibiotics in staphylococci can be due to $\beta$-lactamases, alterations of the penicillin-binding proteins (PBP) or acquisition of new PBPs (for general reviews, see [5, $35,40,44])$.

The $\beta$-lactamases are differentiated according to their DNA sequences into four classes A-D (= "Ambler"-classes). According to their resistance phenotypes, they are classified into another four groups, one of which consists of eight subgroups (= revised Bush scheme). Staphylococcal $\beta$-lactamases are usually assigned to molecular class A 
and Bush group 2a [35]; they have been found in S. aureus as well as in CNS [6, 40, 67]. In human staphylococci, the $\beta$-lactamase (blaZ) gene is inducibly expressed. The blaZ gene and its regulatory genes have been found to be located on the nonconjugative transposon, Tn552 [67], which is frequently found on plasmids [40]. A study on 58 penicillin resistant and $\beta$-lactamase producing $S$. aureus isolates from bovine mastitis collected in Denmark showed that the blaZ gene was present in all isolates. The majority of the isolates carried the blaZ gene in the chromosome whereas this gene was detected on plasmids of different sizes in four isolates [99]. A recent study on penicillin-resistant staphylococci of bovine origin from Norway [109] identified the $\beta$-lactamase gene cluster including the blaZ gene in close location to the insertion element IS1181 in most of the S. aureus isolates, but associated with IS257 in a single $S$. haemolyticus isolate.

Methicillin resistance in staphylococci is due to the acquisition of a chromosomally localised gene, mecA, that encodes an accessory PBP, called PBP2a or PBP2' [44]. MRSA or methicillin-resistant CNS are widespread in humans, but are still rarely seen in animals. One outbreak of MRSA was described in a veterinary hospital in the United States [93]. S. aureus strains were isolated from horses and, because of the rarity of MRSA isolation from animals, compared with $S$. aureus strains from the hospital staff. Strains from humans and the equine staphylococci exhibited identical macrorestriction patterns. The molecular background of methicillin resistance was not investigated in this study. On the basis of their biochemical and genetic (macrorestriction patterns) properties, strains isolated from both origins were concluded to be closely related. There was speculation that the veterinary staff may be the primary source of infection for horses.

Kawano et al. [29] reported the isolation of methicillin resistance due to the presence of a mecA gene in S. sciuri, S. saprophyticus, and $S$. epidermidis from chickens. In these studies, part of the gene was sequenced and proved to be identical with the corresponding region in mecA genes from human isolates of $S$. aureus and $S$. epidermidis. The horizontal transfer of the mecA gene between the staphylococcal species was evidenced. It may be possible that a chicken coagulase-negative Staphylococcus acquired the mecA gene from humans and then prevailed among chicken staphylococci. In such conditions, the hypothesis of chickens as a reservoir for mecA was given. Wu et al. [108] also described the mecA gene in a diverse collection of $S$. sciuri.

\subsubsection{Resistance to fluoroquinolones}

Fluoroquinolone resistance may be the result of stepwise mutations in the genes coding for the enzymes DNA gyrase ( $g y r)$ and topoisomerase IV (par) [61]. Moreover, efflux of the drugs mediated by multidrug exporters such as NorA may contribute to clinical levels of fluoroquinolone resistance. In contrast to the data on human $S$. aureus strains, very little is known about the genetic basis of fluoroquinolone resistance in animal staphylococci. A study on 429 canine $S$. intermedius isolates obtained between 1996 and 1998 identified four resistant isolates [37]. Attempts to amplify the gyrA region - assumed to be involved in fluoroquinolone resistance - with the PCR primers known to be from $S$. aureus did not yield the expected amplification products in two resistant and two sensitive $S$. intermedius isolates as well as in a sensitive $S$. hyicus isolate [37]. This observation suggested that the gyrA genes from $S$. intermedius and $S$. hyicus differ in their sequences from those seen in $S$. aureus and more basic work is needed to identify mutations in the gyr and par genes possibly involved in fluoroquinolone resistance of animal staphylococci.

\subsubsection{Resistance to sulfonamides and trimethoprim}

Sulfonamide resistance in staphylococci is based on the overproduction of $p$-amino- 
benzoic acid probably due to a chromosomal mutation (sulA). In contrast, trimethoprim resistance is often associated with dihydrofolate reductases which exhibit low affinity to trimethoprim. Two corresponding dihydrofolate reductase $(d f r)$ genes have been observed in staphylococci, $d f r A$ and $d f r B[13,66]$. Gene $d f r A$ together with a gene coding for a thymidylate synthase (thyE) is part of $\mathrm{Tn} 4003$, a non-conjugative transposon often located on large staphylococcal plasmids [66]. So far, no data on the molecular basis of sulfonamide and trimethoprim resistance in animal staphylococci are available.

\subsubsection{Resistance to mupirocin}

Mupirocin (= pseudomonic acid A) is a competitive inhibitor of isoleucyl-tRNA synthetase. It is occasionally used in veterinary medicine to treat canine pyoderma caused by multiresistant $S$. intermedius isolates. Clinical resistance in staphylococci has been reported to be due to the expression of the gene тирA which codes for an isoleucyltRNA synthetase with reduced affinity to mupirocin [26]. Gene mupA has been identified on plasmids of different sizes in $S$. aureus of human origin [48], but also in a single $S$. aureus isolate from a mountain goat [105].

\subsection{Horizontal gene transfer}

With regard to the spread of antimicrobial resistance genes within a bacterial population, plasmids play an extraordinary role, either as carriers of originally plasmid-borne resistance genes or as vectors for transposon-borne resistance genes. The detection of the same plasmid-borne resistance properties in staphylococci of different species and different animal origin leads to the question of whether the respective plasmids represent structurally related or different elements. To answer this question, plasmids were initially subjected to restriction analyses. Restriction mapping provides a simple tool to rapidly obtain information on the structure of resistance plasmids. These informations will also be helpful in further studies including cloning experiments and sequence analyses. Restriction maps of tet $(\mathrm{K})$ - and tet $(\mathrm{L})$-carrying plasmids from animal staphylococci are displayed in [78], those of erm(C)-carrying plasmids in [90], and maps of $\mathrm{Cm}$ resistance plasmids as detected in human $S$. aureus are shown in [24]. In many cases, comparative analysis of these maps revealed close structural relationships of plasmids carrying the same resistance gene. Therefore, it was concluded that such plasmids have most probably not evolved independently from one another, but may have been exchanged by horizontal gene transfer processes between isolates of the same or different staphylococcal species. Exchange of resistance plasmids has largely contributed to the emergence of resistance to a number of antimicrobial agents. In staphylococci, such transfer events are mainly based on transduction or conjugation/mobilisation [79].

Transduction involves the presence of a transducing phage. The respective phages known in $S$. aureus have a genome size of approximately $45 \mathrm{kbp}$ and therefore can only efficiently transduce plasmids of less than $45 \mathrm{kbp}$. Phage particles transducing small plasmids contain the plasmids as linear concatemers. Transduction of small plasmids has been demonstrated with the tet $(\mathrm{K})$-carrying plasmid pT181 and the catA-carrying plasmid pC194 [40]. Co-transduction of small plasmids mediating $\mathrm{Sm}$, Tc, or $\mathrm{Cm}$ resistance has also been observed (for a review see [40]). Such plasmids are assumed to undergo a recombination-dependent linkage during transduction. On reaching the new host cell, this linkage is usually resolved, however in some cases, stable plasmid cointegrates are also observed. The rarely detected naturally occurring $\mathrm{Cm} / \mathrm{Sm}$ resistance plasmids [24, 76, 77] may represent examples for such cointegrates. Efficient transduction also requires specific receptors for the attachment of the 
transducing phages on the surface of the new host cell. Such receptors are usually only present in closely related bacteria. Among staphylococci, these receptors may not be available in isolates of different species. The use of a human, bovine and canine set of phages to lysotype the respective $S$. aureus isolates illustrates that even isolates of the same staphylococcal species, but obtained from different animal sources, may not be susceptible to the same phages. Thus transduction may only be of importance for the transfer of resistance properties between closely related staphylococci.

However, indistinguishable resistance plasmids have also been detected in isolates of distantly related staphylococcal species from human and animal sources. The most probable explanation for this is a transfer by either conjugation or mobilisation. In contrast to the situation in human staphylococci [40], only a few large conjugative plasmids, carrying the $a a c A-a p h D$ aminoglycoside resistance gene $[31,105]$ have been detected in animal staphylococci. In addition to conjugative plasmids, conjugative transposons, e.g. those of the $\operatorname{Tn} 916 / \operatorname{Tn} 1545$ family, have been detected in staphylococci and other gram-positive bacteria [15]. Some of these transposons, such as Tn916, carry only the Tc resistance gene tet $(\mathrm{M})$, while others like $\operatorname{Tn} 1545$, carry additional resistance genes, such as the $\mathrm{Km} / \mathrm{Nm}$ resistance gene $\operatorname{aphA}-3\left(=\operatorname{aph}\left(3^{\prime}\right)-\mathrm{IIIa}\right)$ and the $\mathrm{MLS}_{\mathrm{B}}$ resistance gene $\operatorname{erm}(\mathrm{B})$. Although the $\operatorname{tet}(\mathrm{M})$ genes were identified in a wide variety of different staphylococcal species of animal origin [91], the entire transposons have not yet been detected in animal staphylococci. Conjugative plasmids and transposons may also provide their transfer apparatus to small non-conjugative, but mobilisable co-resident plasmids. For example, the $\mathrm{Cm}$ resistance plasmid pC221 carries reading frames for two different mobilisation genes, $m o b A$ and $m o b B$. Virtually indistinguishable plasmids to pC221 have also been identified in various staphylococci of animal origin. In the majority of cases, isolates carrying
pC221-like plasmids harboured additional small tet $(\mathrm{K})-$, str- or erm $(\mathrm{C})$-carrying plasmids, none of which is known to carry mob genes. However, since the Mob proteins originating from one plasmid are available to all plasmids in the same cell, other small plasmids can be co-mobilised, provided they have an oriT ("origin of transfer") region to which the Mob proteins can bind. The prototype of erm(C)-carrying plasmids, pE194, has been reported to be non-mobilisable [54] and this is in agreement with the observations that $\mathrm{pE} 194$-like plasmids have not been detected in human staphylococci and only a single pE194-related plasmid has been seen so far in a porcine $S$. equorum isolate [38]. In contrast, small erm(C)-carrying plasmids of 2.3-2.5 kbp were detected in S. aureus from humans [40] and in a large number of staphylococcal species from various animal sources [39].

Staphylococci, however, also share a number of resistance genes with other grampositive bacteria. This may be due to the location of the resistance genes on conjugative transposons of the afore mentioned Tn916/Tn1545 family which commonly exhibits a broad host range. Conjugative broad host range resistance plasmids, mostly of streptococcal or enterococcal origin, have also been described, and have shown to be able to replicate and express their resistance genes in isolates of other gram-positive genera. Such plasmids include the $30.2 \mathrm{kbp}$ plasmid pIP501 which carries a catA and an $\operatorname{erm}(\mathrm{B})$ gene and the $26.5 \mathrm{kbp}$ plasmid pAM $\beta 1$ which harbours an erm(B) gene. The host range of plasmid pIP501 includes the genera Staphylococcus, Streptococcus, Enterococcus, Clostridium, Listeria, and Pediococcus, while that of plasmid pAM $\beta 1$ comprises the genera Staphylococcus, Streptococcus, Enterococcus, Clostridium, Bacillus, and Lactobacillus [41]. Some of the small resistance plasmids, such as tet $(\mathrm{K})-$, tet $(\mathrm{L})-$, catA-, aadD- or $\operatorname{erm}(\mathrm{C})$ carrying plasmids, have also been reported to be able to replicate not only in staphylococci, but also in isolates of the genus 
Table V. Examples of the presence of certain resistance genes in staphylococci and members of other gram-positive genera.

\begin{tabular}{|c|c|c|c|c|c|c|}
\hline \multirow[t]{2}{*}{ Resistance gene } & \multicolumn{6}{|c|}{ Presence in } \\
\hline & Staphylococcus & Bacillus & Streptococcus & Enterococcus & Listeria & Clostridium \\
\hline$a a c \mathrm{~A}-a p h \mathrm{D}$ & + & + & + & + & - & - \\
\hline$a a d \mathrm{D}$ & + & + & - & - & - & - \\
\hline str & + & - & - & - & - & - \\
\hline $\operatorname{catA}(\mathrm{pC} 221)$ & + & + & + & + & + & + \\
\hline catA(pC223) & + & - & + & + & + & - \\
\hline catA(pC194) & + & - & + & + & - & - \\
\hline $\operatorname{erm}(\mathrm{A})$ & + & - & - & - & - & - \\
\hline $\operatorname{erm}(\mathrm{B})$ & + & + & + & + & + & + \\
\hline $\operatorname{erm}(\mathrm{C})$ & + & + & - & - & - & - \\
\hline $\operatorname{erm}(\mathrm{F})$ & + & + & + & $t^{\mathrm{a}}$ & - & + \\
\hline $\operatorname{tet}(\mathrm{K})$ & + & + & - & - & - & - \\
\hline $\operatorname{tet}(\mathrm{L})$ & + & + & + & + & - & - \\
\hline $\operatorname{tet}(\mathrm{M})$ & + & + & + & + & + & + \\
\hline $\operatorname{tet}(\mathrm{O})$ & + & - & + & + & - & - \\
\hline
\end{tabular}

${ }^{\text {a }}$ Functionally active in Enterococcus after in vitro transfer [14].

Bacillus [54]. Table V gives an example of the occurrence of selected resistance genes of staphylococci in bacteria of other grampositive genera.

During the last decade, resistance plasmids isolated from various staphylococcal species of animal origin have been transferred under laboratory conditions into selected plasmid-free $S$. aureus or $S$. carnosus recipient strains which lack restriction/modification systems. Despite the fact that such experiments are essential for the identification of resistance plasmids from animal staphylococci, these approaches do not reflect the in vivo situation. Thus it should be noted that our current knowledge on the role of isolates of different staphylococcal species of animal origin as recipients for resistance plasmids and transposons is very limited. A few mating experiments using naturally occurring $S$. intermedius and $S$. hyicus isolates as recipients with enterococcal donors identified the $S$. intermedius isolates as very poor recipients for resistance plasmids whereas transposons were readily accepted [52]. This observation was in accordance with the findings on the pref- erential occurrence of other transposonborne resistance genes, such as tet $(\mathrm{M})$ [80, 91] and erm(B) [20] in S. intermedius. In contrast, the $S$. hyicus recipients accepted the conjugative aadA-aphD-carrying resistance plasmids. Once again, this is in accordance with previous reports on resistance plasmids in S. hyicus and their structural similarities to resistance plasmids seen in other staphylococcal species from humans and animals $[63,71,72,81]$. Thus the spread of a certain plasmid or transposon may also be strongly influenced by factors in the host cells, such as restriction/modification systems or other plasmid exclusion systems which in the majority of cases remain to be identified in animal staphylococci. Nevertheless, these factors may account for striking differences between isolates of different staphylococcal species in their ability to acquire foreign resistance genes.

Finally, access of the staphylococci to a wide gene pool - as it is present in mixed bacterial populations on the skin, but also on the mucosal membranes of the respiratory and intestinal tract - may distinctly favour the acquisition of resistance genes. 
In this regard, the relatively low resistance rates observed among $S$. aureus isolates from bovine mastitis may be explained by their limited possibilities to acquire resistance genes in a virtually sterile compartment such as the udder where no indigenous bacterial flora is present. In contrast, the wide variety of resistance genes encountered in S. intermedius and $S$. hyicus isolates may be the result of exchanges of resistance genes within bacterial mixed populations on the skin.

\section{CONCLUSION}

Staphylococci of animal origin exhibit resistance to a number of antimicrobial agents. Nevertheless, most of the published resistance rates of animal $S$. aureus are lower than comparable resistance rates from clinical human isolates. However, resistance rates of animal staphylococci vary widely according to animal species, staphylococcal species and resistance properties. It is difficult - if not impossible - to compare the data available from the numerous reports due to the non-uniformity of the methods applied, the criteria used for validation of the results, and the often missing background data on the epidemiological relatedness of the isolates tested. Standardised methodology and validation criteria will be key requirements for the future and should be adopted by national monitoring programmes. New technologies, such as DNA chips, which may be able to combine the detection of specific resistance genes with typing methods will help to generate powerful data on the occurrence and the spread of certain resistance genes among different staphylococcal isolates, but will also help to identify resistant clones that spread within animal populations. The basic work on the identification of resistance genes in animal staphylococci provides helpful information for the design of suitable probes to be used for DNA chip technology. The use of new large through-put screening systems will broaden our future knowledge on resistance genes in animal staphylococci, but will also allow to rapidly detect changes in resistance patterns as well as the emergence of new resistance genes.

As bright as the future looks for new diagnostic tools, prospects concerning new developments of antistaphylococcal drugs for use in animals seem less encouraging. There are a number of promising new drugs in clinical trials or under development, including oxazolidinones, ketolides, glycylcyclines, but also new cephalosporins and fluoroquinolones [61]. But whenever these compounds will be available for therapy, their use will be restricted to human medicine. Thus staphylococcal infections in animals will probably be treated in the future with the same antimicrobial agents as those currently available. Due to the current lack of specific immunological tools for the prophylaxis of staphylococcal infections, antimicrobial chemotherapy is still the most important measure in the control of staphylococcal infections. Bearing in mind the risk of resistance development, veterinary surgeons need to strictly follow prudent-use guidelines at least to retain the efficacy of the current set of antimicrobial agents licensed for use in animals.

\section{REFERENCES}

[1] Aarestrup F.M., Jensen N.E., Development of penicillin resistance among Staphylococcus aureus isolated from bovine mastitis in Denmark and other countries, Microb. Drug Resist. 4 (1998) 247-256.

[2] Aarestrup F.M., Wegener H.C., Rosdahl V.T., A comparative study of Staphylococcus aureus strains isolated from bovine subclinical mastitis during 1952-1956 and 1992, Acta Vet. Scand. 36 (1995) 237-243.

[3] Aarestrup F.M., Bager F., Jensen N.E., Madsen M., Meyling A., Wegener H.C., Resistance to antimicrobial agents used for animal therapy in pathogenic-, zoonotic- and indicator bacteria isolated from different food animals in Denmark: a baseline study for the Danish Integrated Antimicrobial Resistance Monitoring Programme (DANMAP), APMIS 106 (1998) 745-770.

[4] Aarestrup F.M., Agers Y., Ahrens P., Jorgensen J.C., Madsen M., Jensen L.B., Antimicrobial 
susceptibility and presence of resistance genes in staphylococci from poultry, Vet. Microbiol. 74 (2000) 353-364.

[5] Alekshun M.N., Levy S.B., Bacterial drug resistance: response to survival threats, in: Storz G., Hengge-Aronis R. (Eds.), Bacterial stress responses ASM Press, Washington D.C., 2000, pp. 323-366.

[6] Archer G.L., Climo M.W., Antimicrobial susceptibility of coagulase-negative staphylococci, Antimicrob. Agents Chemother. 38 (1994) 22312237.

[7] Ayliffe G.A., The progressive intercontinental spread of methicillin-resistant Staphylococcus aureus, Clin. Infect. Dis. 24 Suppl. 1 (1997) S74S79.

[8] Boerlin P., Burnens A.P., Frey J., Kuhnert P., Nicolet J., Molecular epidemiology and genetic linkage of macrolide and aminoglycoside resistance in Staphylococcus intermedius of canine origin, Vet. Microbiol. 79 (2001) 155-169.

[9] Brückler J., Schwarz S., Untermann F., Staphylokokken-Infektionen und -Enterotoxine, in: Blobel H., Schliesser T. (Eds.), Handbuch der bakteriellen Infektionen bei Tieren, Band II, Teil 1 (2. Aufl.), Gustav Fischer Verlag, Jena, 1994, pp. 1251.

[10] Cardoso M., Schwarz S., Characterization of the chloramphenicol acetyltransferase variants encoded by the plasmids pSCS6 and pSCS7 from Staphylococcus aureus, J. Gen. Microbiol. 138 (1992) 275-281.

[11] Cardoso M., Schwarz S., Chloramphenicol resistance plasmids in Staphylococcus aureus isolated from bovine subclinical mastitis, Vet. Microbiol. 30 (1992) 223-232.

[12] Cardoso M., Schwarz S., Nucleotide sequence and structural relationships of a chloramphenicol acetyltransferase encoded by the plasmid pSCS6 from Staphylococcus aureus, J. Appl. Bacteriol. 72 (1992) 289-293.

[13] Charpentier E., Courvalin P., Emergence of the trimethoprim resistance gene $d f r D$ in Listeria monocytogenes BM4293, Antimicrob. Agents Chemother. 41 (1997) 1134-1136.

[14] Chung W.O., Werckenthin C., Schwarz S., Roberts M.C., Host range of the ermF rRNA methylase gene in bacteria of human and animal origin, J. Antimicrob. Chemother. 43 (1999) 514.

[15] Clewell D.B., Flannagan S.E., The conjugative transposons of gram-positive bacteria, in: Clewell D.B. (Ed.), Bacterial conjugation, Plenum Press, New York, 1993, pp. 369-393.

[16] Cox H.U., Hoskins J.D., Roy A.F., Newman S.S., Luther D.G., Antimicrobial susceptibility of coagulase-positive staphylococci isolated from Louisiana dogs, Am. J. Vet. Res. 45 (1984) 20392042.

[17] Craven N., Anderson J.C., Jones T.O., Antimicrobial drug susceptibility of Staphylococcus aureus isolated from bovine mastitis, Vet. Rec. 118 (1986) 290-291.

[18] De Oliveira A.P., Watts J.L., Salmon S.A. Aarestrup F.M., Antimicrobial susceptibility of Staphylococcus aureus isolated from bovine mastitis in Europe and the United States, J. Dairy Sci. 83 (2000) 855-862.

[19] Devriese L.A., Hasebrouck F., Hommez J., Vandermeesch R., A 25-year survey of antibiotic susceptiblity testing in Staphylococcus aureus from bovine mastitis in Belgium, with special reference to penicillinase, Vlaams Diergeneeskd. Tijdschr. 66 (1997) 170-173.

[20] Eady E.A., Ross J.I., Tipper J.L., Walters C.E., Cove J.H., Noble W.C., Distribution of genes encoding erythromycin ribosomal methylases and an erythromycin efflux pump in epidemiologically distinct groups of staphylococci, J. Antimicrob. Chemother. 31 (1993) 211-217.

[21] Euzeby J.P., List of Bacterial Names with Standing in Nomenclature: a folder available on the Internet, Int. J. Syst. Bacteriol. 47 (1997) 590592.

[22] Franklin A., Horn af Rantzien M., Antimicrobial drug susceptibility of Staphylococcus aureus strains isolated from bovine milk, Nord. Vetmed. 35 (1983) 460-464.

[23] Frost A.J., O'Boyle D., The resistance to antimicrobial agents of Staphylococcus aureus isolated from the bovine udder, Aust. Vet. J. 57 (1981) 262-267.

[24] Gillespie M.T., Skurray R.A., Structural relationships among chloramphenicol resistance plasmids of Staphylococcus aureus, FEMS Microbiol. Lett. 51 (1988) 205-210.

[25] Greene R.T., Schwarz S., Small antibiotic resistance plasmids in Staphylococcus intermedius, Zentralbl. Bakteriol. 276 (1992) 380-389.

[26] Hodgson J.E., Curnock S.P., Dyke K.G.H., Morris R., Sylvester D.R., Gross M.S., Molecular characterization of the gene encoding high-level mupirocin resistance in Staphylococcus aureus J2870, Antimicrob. Agents Chemother. 38 (1994) 1205-1208.

[27] Jensen L.B., Frimodt-Moller N., Aarestrup F.M., Presence of erm gene classes in gram-positive bacteria of animal and human origin in Denmark, FEMS Microbiol. Lett. 170 (1999) 151-158.

[28] John J., Hesselbarth J., Schwarz S., Biochemical and molecular characterization of Staphylococcus sciuri, Med. Microbiol. Lett. 4 (1995) 346353 .

[29] Kawano J., Shimizu A., Saitoh Y., Yagi M., Saito T., Okamoto R., Isolation of methicillin-resistant coagulase-negative staphylococci from chickens, J. Clin. Microbiol. 34 (1996) 2072-2077.

[30] Kloos W.E., Natural populations of the genus Staphylococcus, Annu. Rev. Microbiol. 34 (1980) 559-592. 
[31] Lange C., Schwarz S., Molecular characterization of the aacA/aphD resistance gene region on plasmids from animal staphylococci, in: Proceedings of the 9th International Symposium on Staphylococci and Staphylococcal Infections, Kolding, Denmark Session C, P-9, 2000, p. 51.

32] Lange C., Cardoso M., Senczek D., Schwarz S., Molecular subtyping of Staphylococcus aureus isolates from cases of bovine mastitis in Brazil, Vet. Microbiol. 67 (1999) 127-141.

[33] Lilenbaum W., Nunes E.L., Azeredo M.A., Prevalence and antimicrobial susceptibility of staphylococci isolated from the skin surface of clinically normal cats, Lett. Appl. Microbiol. 27 (1998) 224-228.

[34] Lilenbaum W., Esteves A.L., Souza G.N., Prevalence and antimicrobial susceptibility of staphylococci isolated from saliva of clinically normal cats, Lett. Appl. Microbiol. 28 (1999) 448-452.

[35] Livermore D.M., Beta-Lactamases in laboratory and clinical resistance, Clin. Microbiol. Rev. 8 (1995) 557-584

[36] Lloyd D.H., Lamport A.I., Feeney C., Sensitivity to antibiotics amongst cutaneous and mucosal isolates of canine pathogenic staphylococci in the UK, 1980-96, Vet. Dermatol. 7 (1996) 171-175.

[37] Lloyd D.H., Lamport A.I., Noble W.C., Howell S.A., Fluoroquinolone resistance in Staphylococcus intermedius, Vet. Dermatol. 10 (1999) 249-252.

[38] Lodder G., Schwarz S., Gregory P., Dyke K.G.H., Tandem duplication in erm $\mathrm{C}$ translational attenuator of the macrolide-lincosamide-streptogramin B resistance plasmid pSES6 from Staphylococcus equorum, Antimicrob. Agents Chemother. 40 (1996) 215-217.

[39] Lodder G., Werckenthin C., Schwarz S., Dyke K.G.H., Molecular analysis of naturally occurring erm $\mathrm{C}$-encoding plasmids in staphylococci isolated from animals with and without previous contact with macrolide/lincosamide antibiotics, FEMS Immunol. Med. Microbiol. 18 (1997) 7-15.

[40] Lyon B.R., Skurray R., Antimicrobial resistance of Staphylococcus aureus: genetic basis, Microbiol. Rev. 51 (1987) 88-134.

[41] Macrina F.L., Archer G.L., Conjugation and broad host range plasmids in streptococci and staphylococci, in: Clewell D.B. (Ed.), Bacterial conjugation, Plenum Press, New York, 1999, pp. 313329 .

[42] Martel J.L., Chaslus-Dancla E., Coudert M., Poumarat F., Lafont J.P., Survey of antimicrobial resistance in bacterial isolates from diseased cattle in France, Microb. Drug Resist. 1 (1995) 273-283.

[43] Martin H., Maris P., Antiseptic and antibiotic resistance of 310 gram-positive strains isolated from udders after use of post-milking teat germicides, Vet. Res. 26 (1995) 43-56.

[44] Massova I., Mobashery S., Kinship and diversification of bacterial penicillin-binding proteins and beta-lactamases, Antimicrob. Agents Chemother. 42 (1998) 1-17.

[45] McKenzie T., Hoshino T., Tanaka T., Sueoka N., The nucleotide sequence of pUB110: some salient features in relation to replication and its regulation, Plasmid 15 (1986) 93-103.

[46] Medleau L., Long R.E., Brown J., Miller W.H., Frequency and antimicrobial susceptibility of Staphylococcus species isolated from canine pyodermas, Am. J. Vet. Res. 47 (1986) 229-231.

[47] Nawaz M.S., Khan A.A., Khan S.A., Paine D.D., Pothuluri J.V., Cerniglia C.E., Biochemical and molecular characterization of erthromycin-resistant avian Staphylococcus spp. isolated from chickens, Poult. Sci. 78 (1999) 1191-1197.

[48] Needham C., Rahman M., Dyke K.G.H., Noble W.C., An investigation of plasmids from Staphylococcus aureus that mediate resistance to mupirocin and tetracycline, Microbiology 140 (1994) 2577-2583.

[49] Noble W.C., Allaker R.P., Staphylococci on the skin of pigs: isolates from two farms with different antibiotic policies, Vet. Rec. 130 (1992) 466468

[50] Noble W.C., Kent L., Antibiotic resistance in Staphylococcus intermedius isolated from cases of pyoderma in the dog, Vet. Dermatol. 3 (1992) 71-74.

[51] Noble W.C., Rahman M., Lloyd D.H., Plasmids in Staphylococcus hyicus, J. Appl. Bacteriol. 64 (1988) 145-149.

[52] Noble W.C., Rahman M., Karadec T., Schwarz S., Gentamicin resistance gene transfer from Enterococcus faecalis and E. faecium to Staphylococcus aureus, $S$. intermedius and S. hyicus, Vet. Microbiol. 52 (1996) 143-152.

[53] Normand E.H., Gibson N.R., Reid S.W., Carmichael S., Taylor D.J., Antimicrobial-resistance trends in bacterial isolates from companion animal community practice in the UK, Prev. Vet. Med. 46 (2000) 267-278.

[54] Novick R.P., Staphylococcal plasmids and their replication, Annu. Rev. Microbiol. 43 (1989) 537 565.

[55] Owens W.E., Watts J.L., Antimicrobial susceptibility and beta-lactamase testing of staphylococci isolated from dairy herds, J. Dairy Sci. 71 (1988) 1934-1939.

[56] Pedersen K., Wegener H.C., Antimicrobial susceptibility and rRNA gene restriction patterns among Staphylococcus intermedius from healthy dogs and from dogs suffering from pyoderma or otitis externa, Acta Vet. Scand. 36 (1995) 335342

[57] Pereira M.S., Siqueira-Junior J.P., Antimicrobial drug resistance in Staphylococcus aureus isolated from cattle in Brazil, Lett. Appl. Microbiol. 20 (1995) 391-395.

[58] Perrin-Coullioud I., Martel J.L., Coudert M., Bilan de l'épidémiosurveillance de l'antibiorésistance de 
Staphylococcus aureus en pathologie bovine, Rev. Méd. Vét. (Toulouse) 139 (1988) 709-718.

[59] Perrin-Coullioud I., Martel J.L., Brouillet P., Fedida M., Identification et sensibilité aux antibiotiques des diverses espèces de staphylocoques associées à des mammites bovines inapparentes et subcliniques - Résultats d'une enquête régionale, Rev. Méd. Vét. (Toulouse) 142 (1991) 39-47.

[60] Phillips W.E. Jr., Williams B.J., Antimicrobial susceptibility patterns of canine Staphylococcus intermedius isolates from veterinary clinical specimens, Am. J. Vet. Res. 45 (1984) 2376-2379.

[61] Projan S.J., Antibiotic resistance in the staphylococci, in: Fischetti V.A., Novick R.P., Portnoy D.A., Rood, J.I. (Eds.), Gram-positive pathogens, ASM Press, Washington D.C., 2000, pp. 463470.

[62] Projan S.J., Moghazeh S., Novick R.P., Nucleotide sequence of pS194, a streptomycinresistance plasmid from Staphylococcus aureus, Nucleic Acids Res. 16 (1988) 2179-2187.

[63] Rahman M., Kent L., Noble W.C., Streptomycin and tetracycline resistance plasmids in Staphylococcus hyicus and other staphylococci, J. Appl. Bacteriol. 70 (1991) 211-215.

[64] Roberts M.C., Tetracycline resistance determinants: mechanisms of action, regulation of expression, genetic mobility, and distribution, FEMS Microbiol. Rev. 19 (1996) 1-24.

[65] Rouch D.A., Byrne M.E., Kong Y.C., Skurray R.A., The $a a c A-a p h D$ gentamicin and kanamycin resistance determinant of Tn4001 from Staphylococcus aureus: expression and nucleotide sequence analysis, J. Gen. Microbiol. 133 (1987) 3039-3052.

[66] Rouch D.A., Messerotti L.J., Loo L.S., Jackson C.A., Skurray R.A., Trimethoprim resistance transposon Tn4003 from Staphylococcus aureus encodes genes for a dihydrofolate reductase and thymidylate synthetase flanked by three copies of IS257, Mol. Microbiol. 3 (1989) 161-175.

[67] Rowland S.J., Dyke K.G.H., Characterization of the staphylococcal beta-lactamase transposon Tn552, EMBO J. 8 (1989) 2761-2773.

[68] Schwarz S., Plasmid-encoded resistance to tetracycline in Staphylococcus haemolyticus, Lett. Appl. Microbiol. 15 (1992) 142-145.

[69] Schwarz S., Emerging chloramphenicol resistance in Staphylococcus lentus from mink following chloramphenicol treatment: characterisation of the resistance genes, Vet. Microbiol. 41 (1994) 51-61.

[70] Schwarz S., Blobel H., Plasmids and resistance to antimicrobial agents and heavy metals in Staphylococcus hyicus from pigs and cattle, J. Vet. Med. B 36 (1989) 669-673.

[71] Schwarz S., Blobel H., A new streptomycinresistance plasmid from Staphylococcus hyicus and its structural relationship to other staphylococcal resistance plasmids, J. Med. Microbiol. 32 (1990) 201-205.
[72] Schwarz S., Blobel H., Isolation and restriction endonuclease analysis of a tetracycline resistance plasmid from Staphylococcus hyicus, Vet. Microbiol. 24 (1990) 113-122.

[73] Schwarz S., Blobel H., Isolation of a plasmid from "canine" Staphylococcus epidermidis mediating constitutive resistance to macrolides and lincosamides, Comp. Immunol. Microbiol. Infect. Dis. 13 (1990) 209-216.

[74] Schwarz S., Cardoso M., Molecular cloning, purification, and properties of a plasmid-encoded chloramphenicol acetyltransferase from Staphylococcus haemolyticus, Antimicrob. Agents Chemother. 35 (1991) 1277-1283.

[75] Schwarz S., Cardoso M., Nucleotide sequence and phylogeny of a chloramphenicol acetyltransferase encoded by the plasmid pSCS7 from Staphylococcus aureus, Antimicrob. Agents Chemother. 35 (1991) 1551-1556.

[76] Schwarz S., Grölz-Krug S., A chloramphenicolstreptomycin-resistance plasmid from a clinical strain of Staphylococcus sciuri and its structural relationships to other staphylococcal resistance plasmids, FEMS Microbiol. Lett. 66 (1991) 319322.

[77] Schwarz S., Noble W.C., Structure and putative origin of a plasmid from Staphylococcus hyicus that mediates chloramphenicol and streptomycin resistance, Lett. Appl. Microbiol. 18 (1994) 281284.

[78] Schwarz S., Noble W.C., Tetracycline resistance genes in staphylococci from the skin of pigs, J. Appl. Bacteriol. 76 (1994) 320-326.

[79] Schwarz S., Noble W.C., Aspects of bacterial resistance to antimicrobials used in veterinary dermatological practice, Vet. Dermatol. 10 (1999) 163-176.

[80] Schwarz S., Wang Z., Tetracycline resistance in Staphylococcus intermedius, Lett. Appl. Microbiol. 17 (1993) 88-91.

[81] Schwarz S., Cardoso M., Blobel, H., Plasmidmediated chloramphenicol resistance in Staphylococcus hyicus, J. Gen. Microbiol. 135 (1989) 3329-3336.

[82] Schwarz S., Cardoso M., Blobel H., Plasmidencoded antibiotic resistance in Staphylococcus hyicus, Dtsch. Tierärztl. Wochenschr. 97 (1990) 501-503.

[83] Schwarz S., Cardoso M., Blobel H., Detection of a novel chloramphenicol resistance plasmid from "equine" Staphylococcus sciuri, J. Vet. Med. B 37 (1990) 674-679.

[84] Schwarz S., Cardoso M., Grolz-Krug S., Blobel $\mathrm{H}$., Common antibiotic resistance plasmids in Staphylococcus aureus and Staphylococcus epidermidis from human and canine infections, Zentralbl. Bakteriol. 273 (1990) 369-377.

[85] Schwarz S., Wegener H.C., Blobel H., Plasmidencoded resistance to macrolides and lincosamides in Staphylococcus hyicus, J. Appl. Bacteriol. 69 (1990) 845-849. 
[86] Schwarz S., Spies U., Cardoso M., Cloning and sequence analysis of a plasmid-encoded chloramphenicol acetyltransferase gene from Staphylococcus intermedius, J. Gen. Microbiol. 137 (1991) 977-981.

[87] Schwarz S., Cardoso M., Wegener H.C., Nucleotide sequence and phylogeny of the tet $(\mathrm{L})$ tetracycline resistance determinant encoded by plasmid pSTE1 from Staphylococcus hyicus, Antimicrob. Agents Chemother. 36 (1992) 580588.

[88] Schwarz S., Werckenthin C., Pinter L., Kent L.E., Noble W.C., Chloramphenicol resistance in Staphylococcus intermedius from a single veterinary centre: evidence for plasmid and chromosomal location of the resistance genes, Vet. Microbiol. 43 (1995) 151-159.

[89] Schwarz S., Gregory P.D., Werckenthin C., Curnock S., Dyke K.G.H., A novel plasmid from Staphylococcus epidermidis specifying resistance to kanamycin, neomycin and tetracycline, J. Med. Microbiol. 45 (1996) 57-63.

[90] Schwarz S., Lange C., Werckenthin C., Molecular analysis of the macrolide-lincosamide resistance gene region of a novel plasmid from Staphylococcus hyicus, J. Med. Microbiol. 47 (1998) 63-70.

[91] Schwarz S., Roberts M.C., Werckenthin C., Pang Y., Lange C., Tetracycline resistance in Staphylococcus spp. from domestic animals, Vet. Microbiol. 63 (1998) 217-227.

[92] Schwarz S., Werckenthin C., Kehrenberg C., Identification of a plasmid-borne chloramphenicol-florfenicol resistance gene in Staphylococcus sciuri, Antimicrob. Agents Chemother. 44 (2000) 2530-2533.

[93] Seguin J.C., Walker R.D., Caron J.P., Kloos W.E., George C.G., Hollis R.J., Jones R.N., Pfaller M.A., Methicillin-resistant Staphylococcus aureus outbreak in a veterinary teaching hospital: potential human-to-animal transmission, J. Clin. Microbiol. 37 (1999) 1459-1463.

[94] Shimizu A., Kawano J., Yamamoto C., Kakutani O., Anzai T., Kamada M., Genetic analysis of equine methicillin-resistant Staphylococcus aureus by pulsed-field gel electrophoresis, J. Vet. Med. Sci. 59 (1997) 935-937.

[95] Stephan R., Dura U., Untermann F., Resistance situation and enterotoxin production capacity of Staphylococcus aureus strains from bovine mastitis milk samples, Schweiz. Arch. Tierheilkd. 141 (1999) 287-290.

[96] Todhunter D.A., Cantwell L.L., Smith K.L., Hoblet K.H., Hogan J.S., Characteristics of coagulase-negative Staphylococci isolated from bovine intramammary infections, Vet. Microbiol. 34 (1993) 373-380.

[97] Trolldenier H., Resistenzauswertung veterinärmedizinisch bedeutsamer bakterieller Erreger 1993, BgVV-Heft 10/1995, 1995.
[98] Trolldenier H., Development of resistance in infectious agents of agricultural animals in Germany (1990-1994) - a review [in German], Dtsch. Tierärztl. Wochenschr. 103 (1996) 256260.

[99] Vesterholm-Nielsen M., Øholm Larsen M., Olsen J.E., Aarestrup F.M., Occurrence of the blaZ gene in penicillin resistant Staphylococcus aureus isolated from bovine mastitis in Denmark, Acta Vet. Scand. 40 (1999) 279-286.

[100] Watts J.L., Salmon S.A., Activity of selected antimicrobial agents against strains of Staphylococcus aureus isolated from bovine intramammary infections that produce beta-lactamase, J. Dairy Sci. 80 (1997) 788-791.

[101] Wegener H.C., Schwarz S., Antibioticresistance and plasmids in Staphylococcus hyicus isolated from pigs with exudative epidermitis and from healthy pigs, Vet. Microbiol. 34 (1993) 363-372.

[102] Wegener H.C., Watts J.L., Salmon S.A., Yancey R.J. Jr., Antimicrobial susceptibility of Staphylococcus hyicus isolated from exudative epidermitis in pigs, J. Clin. Microbiol. 32 (1994) 793-795.

[103] Werckenthin C., Schwarz S., Molecular analysis of the translational attenuator of a constitutively expressed erm(A) gene from Staphylococcus intermedius, J. Antimicrob. Chemother. 46 (2000) 785-788.

[104] Werckenthin C., Schwarz S., Dyke K.G.H., Macrolide-lincosamide-streptogramin B resistance in Staphylococcus lentus results from the integration of part of a transposon into a small plasmid, Antimicrob. Agents Chemother. 40 (1996) 2224-2225.

[105] Werckenthin C., Schwarz S., Roberts M.C., Integration of pT181-like tetracycline resistance plasmids into large staphylococcal plasmids involves IS257, Antimicrob. Agents Chemother. 40 (1996) 2542-2544.

[106] Werckenthin C., Schwarz S., Westh H., Structural alterations in the translational attenuator of constitutively expressed ermC genes, Antimicrob. Agents Chemother. 43 (1999) 1681-1685.

[107] Witte W., Diagnostics, typing, and taxonomy, in: Fischetti V.A., Novick R.P., Portnoy D.A., Rood, J.I. (Eds.), Gram-positive pathogens, ASM Press, Washington D.C., 2000, pp. 309316.

[108] Wu S., De Lencastre H., Tomasz A. Genetic organization of the mecA region in methicillinsusceptible and methicillin-resistant strains of Staphylococus sciuri, J. Bacteriol. 180 (1998) 236-242.

[109] Yazdankhah S.P., Sørum H., Oppegaard H. Comparison of genes involved in penicillin resistance in staphylococci of bovine origin, Microb. Drug Resist. 6 (2000) 29-36. 